\title{
Sistem Monitoring Penggunaan Beban Pada Proses Pengosongan Baterai 100WP Menggunakan Sensor PZEM-004T
}

\author{
Sitti Amalia ${ }^{1}$, Rafika Andari ${ }^{*}$, Yopi Nofrizal ${ }^{3}$ \\ 1,2,3Prodi Teknik Eektro Institut Teknologi Padang*E-mail : rafika.andari09@gmail.com
}

\begin{abstract}
In this study, a prototype tool of plts battery discharge monitoring system was created that aims to facilitate in monitoring plts system, solar panel battery usage monitoring system equipped with arduino microcontroller, current sensor, voltage and power that has been calibrated, so that the data acquisition system integrated in arduino microcontroller based system can be obtained in real time. From the results of the study, according to the microcontroller planner used in this final task is arduino UNO328 and sensor PZEM-004T. This monitoring tool is capable of reading voltage, current, power, cosphi and battery capacity in percent at the time of load supply.
\end{abstract}

Kata kunci: monitoring system, solar cell, battery.

\section{Pendahuluan}

Daerah di perkebunan Dhamasraya merupakan salah satu daerah yang hingga saat ini akses masyarakat terhadap energi masih sangat terbatas, salah satu faktor penyebab keterbatasan layanan energi listrik disebabkan oleh keadaan geografis daerah tersebut sehingga sulit untuk dijangkau oleh jaringan listrik yang disediakan oleh layanan listrik negara (PLN). Ada beberapa sumber yang dapat diperbaharuhi yang tersedia dimana dapat digunakan dalam skala besar untuk menghasilkan energi listrik di daerah terpencil, salah satunya dengan cara memanfaatkan energi terbaharukan seperti Pembangkit Listrik Tenaga Surya (PLTS) [1].

Energi surya merupakan energi yang dapat dikonversikan menjadi energi listrik untuk dimanfaatkan oleh manusia dalam memenuhi kebutuhan energi yang sangat diperlukan pada masa-masa sekarang ini.

Salah satu masalah yang dialami oleh PLTS ialah terjadinya degradasi arus bahkan kehilangan kemampuan konversi energi karena kelalaian pemiliknya, hal ini disebabkan oleh tidak adanya sistem monitoring yang memonitor sistem PLTS pada saat menyuplai beban. Beban listrik adalah peralatan yang menggunakan daya listrik agar dapat berfungsi, ada tiga jenis beban yaitu: beban reaktif, beban induktif, dan beban kapasitif atau lebih dikenal dengan RLC. Untuk itu diperlukan sistem monitoring untuk mengetahui peforma dari PLTS pada saat menyuplai beban.

Sistem monitoring diperlukan agar memudahkan dalam memonitor sistem PLTS. Pada jurnal Ruli siregar pada tahun 2011, tentang sistem monitoring pada sistem PLTS yang hanya mampu melakukan monitoring output pada panel surya menggunakan sensor arus dan sensor tegangan untuk mendapatkan nilai arus, tegangan dan nilai daya dengan data secara otomatis tersimpan pada SC Card.

Menurut Salman [2], pada tahun 2013, yang melakukan penelitian tentang analisis perencanaan penggunaan sistem pembangkit listrik tenaga surya (PLTS) untuk perumahan solar home system (SHS). SHS adalah salah satu sistem PLTS untuk listrik pedesaan sebagai system penerangan rumah secara individual atau desentralisasi dengan daya terpasang relative kecil yaitu sekitar 48-55 Wp. Jumlah daya sebesar $50 \mathrm{Wp}$ per rumah tangga diharapkan dapat memenuhi kebutuhan penerangan, informasi (TV dan Radio) komunikasi). Komponen-komponen utama SHS, terdiri dari: 1. Modul fotovoltaik sebagai catudaya yang menghasilkan energi listrik dari masukan sejumlah energi matahari. 2. Baterai sebagai penyimpan dan pengkondisi energi. 3. Alat pengontrol energy baterai, dan 4. Beban listrik seperti lampu TL, radio, televise dan lain-lain.

Sidik dkk [3], pada tahun 2012, melakukan penelitian tentang potensi dan peranan PLTS sebagai energi alternatif masa depan di indonesia.Sebagai suatu teknologi yang mampu untuk membangkitkan tenaga listrik tanpa menggunakan bahan bakar dengan biaya pembangkitan yang relatif tinggi, maka PLTS merupakan suatu alternatif untuk diterapkan pada wilayah terpencil yang tidak mempunyai potensi energi lainnya. Pengembangan PLTS mempunyai kendala atau masalah sebagai berikut:

1. Biaya pembangkitan listrik dengan PLTS adalah mahal, dan secara ekonomi hanya bisa bersaing dengan PLTD,

2. PLTS akan memerlukan area yang sangat luas, dimana untuk pembangkitan $100 \mathrm{Wp}$ akan 
memerlukan sekitar $1 \mathrm{M} 2$.

3. LTS hanya membangkitkan listrik pada siang hari sehingga akan memerlukan unit penyimpan daya atau accu/baterai untuk penggunaan listrik di malam hari.

4. Saat ini seluruh kebutuhan silicon cristalline sebagai bahan dasar pembuatan sel surya di datangkan dari luar negeri dan belum diproduksi di Indonesia, padahal potensi pasir silika Indonesia sangat besar.

5. Pengembangan PLTS memerlukan operasionil, perawatan, perbaikan dan penyediaan suku cadang termasuk accu yang cukup sulit untuk wilayah terpencil. 6. Pengembangan PLTS secara besarbesaran akan membutuhkan standar atau baku mutu produk, cara pemasangan, cara perawatan serta monitoring.

Oleh karena itu perlu dibuat sistem monitoring penggunaan baterai panel surya yang dilengkapi dengan sensor arus, tegangan dan daya yang telah dikalibrasi, sehingga sistem akuisi data yang diintegrasikan pada sistem berbasis mikrokontroler arduino dapat diperoleh secara real time [4].

Berdasarkan permasalahan diatas, penelitian ini bertujuan untuk mengetahui cara kerja sistem monitoring pengosongan baterai PLTS 100Wp menggunakan sensor PZEM004T, mengetahui cara membandingkan hasil yang diperoleh dari pembacaan sensor PZEM-004T dengan perhitungan manual dan mengetahui pengaruh beban terhadap pengosongan baterai PLTS 100Wp.

\section{Tinjauan Pustaka}

\section{A. Pembangkit Listrik Tenaga Surya(PLTS)}

Pembangkit listrik tenaga surya (PLTS) adalah suatu pembangkit listrik yang menggunakan sinar matahari melalui sel surya (photovoltaic) untuk mengkonversikan radiasi sinar foton matahari menjadi energi listrik.

Pembangkit Listrik Tenaga Surya (PLTS) terbagi atas dua konfigurasi yaitu; sistem PLTS konfigurasi On Grid dan sistem PLTSkonfigurasi Off Grid, sebagai berikut:

1. Pembangkit Listrik Tenaga Surya (PLTS) dengan konfigurasi On Grid dimaksudkan untuk lokasi yang sudah terkoneksi dengan energilistrik dan sistem di lokasi memiliki periode operasi siang hari. Disebut ON Gridkarena PLTS dihubungkan (tied) pada sistem eksisting.

2. Pembangkit Listrik Tenaga Surya (PLTS) dengan konfigurasi Off Grid merupakan sistem pembangkit listrik alternatif untuk daerah- daerah terpencil atau daerah-daerah pedesaanyang tidak terjangkau jaringan listrik PLN [5].

\section{B. Sel surya (Solar Cell)}

Sel surya (Solar Cell) atau sel fotovoltaik berasal dari bahasa inggris yaitu "Photovoltaic". Photovoltaic berasal dari duakata yaitu "photo" yang berarti cahaya dan kata "volt" adalah nama satuan pengukuran teganganlistrik. Sel surya (Solar Cell) merupakan sebuah divais semikonduktor yang memilikipermukaan luas yang terdiri dari rangkaian diode tipe " $p$ " dan "n", yang mampu merubah energi listrik [6].

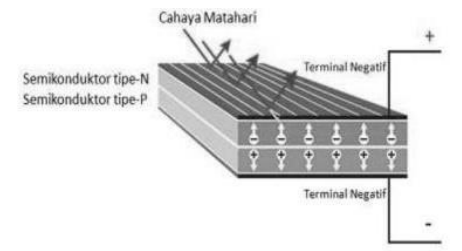

Gambar 1. Struktur Dasar Sel Surya (SolarCell)

\section{Baterai 12V 45AH}

Baterai pembangkit listrik tenaga mataharipada umumnya hanya aktif pada saat siang hari (pada saat sinar matahari ada). Sehingga untuk keperluan malam hari solar cell tidak dapat digunakan.

Kemampuan dari suatu baterai ditentukan oleh kapasitasnya yang diukur dalam satuan Ampere/hour (Ah). Misal baterai dengan kapasitas 5 Ah maksimum dapat mengeluarkan arus sebesar 5 Ah selama satu jam.

\section{Inverter}

Inverter adalah konverter perubah tegangan DC menjadi tegangan AC yang berupa sinyal sinus setelah melalui pembentukan gelombang dan rangkian filter. Tegangan outputnya yang dihasilkan harus stabil baik amplitude tegangan maupun frekuensi tegangan yang dihasilkan, distorsi yang rendah, tidak terdapat tegangan transien serta tidak dapat di interupsi oleh suatu keadaan [7].

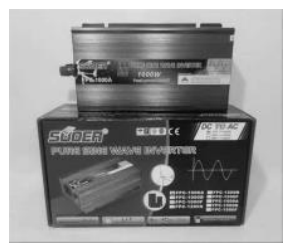

Gambar 2. Inverter PURE SINE WAVE

\section{E. Sensor PZEM-004T}

PZEM-004T adalah sebuah modul elektronik yang berfungsi untuk mengukur : Voltage / Tegangan, Arus, Daya, Frekuensi, Energi dan Power Faktor. 


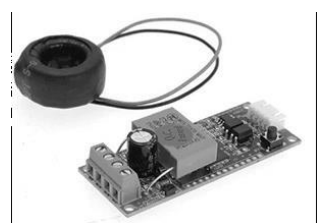

Gambar 3. Sensor PZEM-004T

\section{F. Sensor Tegangan}

Sensor tegagan berfungsi sebagai sensor pendeteksi besaran tegangan pada sistem PLTS. Sensor tegangan DC yang dapat langsungterkoneksi dengan board Arduino. Modul ini pada prinsipnya menggunakan pembagi tegangan resistif, untuk menjalankannya menggunakan tegangan input sebesar $5 \mathrm{~V}$ atau $3,3 \mathrm{~V}$.

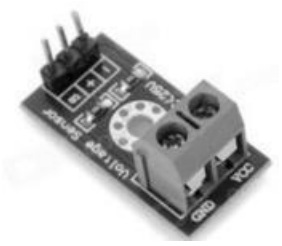

Gambar 4. Sensor tegangan DC

\section{G. Beban listrik}

Beban listrik adalah suatu alat atau beban yang dapat bekerja atau berfungsi apabila dialiriarus listrik yang berpotensial (dapat bekerja dengan memanfaatkan energi listrik).

1. Resistif

$$
\mathrm{P}=V . I
$$

Keterangan :

$$
\mathrm{P}=\text { daya (watt) }
$$$$
\mathrm{V}=\text { tegangan (volt) }
$$

$\mathrm{I}=\operatorname{arus}($ Ampere $)$

\section{Induktif}

$$
\mathrm{P}=V \times I \times \operatorname{Cos} \varphi .
$$

Keterangan :

$\mathrm{P}=$ daya (watt).

$\mathrm{V}=$ tegangan (volt).

$\mathrm{I}=$ arus

(Ampere).

$\operatorname{Cos} \varphi=$ factor daya.

\section{H. Monitoring}

Sistem monitoring penggunaan beban pada proses pengosongan baterai PLTS. Mengetahui nilai eror pada pembacaan alat monitoring dengan menggunakan persamaan sebagai berikut:

$\frac{\text { hasil pembacaan sensor-pembacaan alat ukur }}{\text { hasil pembacaan sensor }} \times 100$.

Untuk menghitung nilai rata-rata kesalahan, dapat dilihat pada persamaan berikut:

rata - rata kesalahan $=$

$\frac{\text { jumlah presentase kesalahan }}{\text { jumlah data }} \times 100 \%$

Menghitung daya sebenarnya, dapat dilihat pada persamaan berikut:

$\mathrm{P}=V \times I \times \operatorname{Cos} \varphi \times t$

Keterangan :

$\mathrm{P}=$ daya (watt)

$\mathrm{V}=$ tegangan (volt)

Menghitung nilai arus yang dihasilkan menggunakan persamaan berikut:

$I=\frac{P}{V x \cos \varphi}$

Untuk menghitung arus sebenarnya, dapat dilihat padapersamaan berikut:

$$
I=\frac{P}{V x \cos \varphi x t e}
$$

\section{Metode Penelitian}

Jenis penelitian ini adalah perancangan dan pembuatan sistem monitoring pengosongan baterai PLTS yang bertujuan untuk memonitor dan melakukan pengkajian serta proses analisa terhadap besarnya nilai penggunaan output yang digunakan pada saat beban terpasang dan dilakukannya suatu pembacaan yang dikonversikan kedalam sistem sensor pzem 004T, pembacaan berupa tegangan, arus dan daya.

Perancangan awal dilakukan dengan menentukan lokasi pembuatan alat, menentukan alat dan bahan yang akan digunakan dalam penelitian, membuat blok diagaram, flowchart, desain mekanik, serta membuat sistem kerja alat yang akan dibuat.

Pada penelitian ini menggunakan alat dan bahan sebagai berikut:

1. Baterai $12 \mathrm{~V} 45 \mathrm{Ah}$

2. Inverter $1000 \mathrm{~W}$

3. Arduino Uno328

4. Sensor PZEM-004T

5. Sensor tegangan DC

6. Lampu pijar $18 \mathrm{~W}$

7. Lampu TL $10 \mathrm{w}$

8. Perangkat keras (hardware)
a. Laptop Prosesor core i7
b. Memori 8 GB (RAM)
c. 1 TB (SATA) HDD

9. Perangkat lunak (software)
a. Sistem Operasi Windows 10 Home
b. Microsoft Office World 2016
c. Proteus
d. Sketchup 2017 
Perancangan skema rangkaian dan mekanik pada alat ini yang dibuat menggunakan beberapa software yang dibutuhkan. Untuk skema rangkaian pada alat ini dibuat menggunakan software proteus yang dapat dilihat pada Gambar 5.

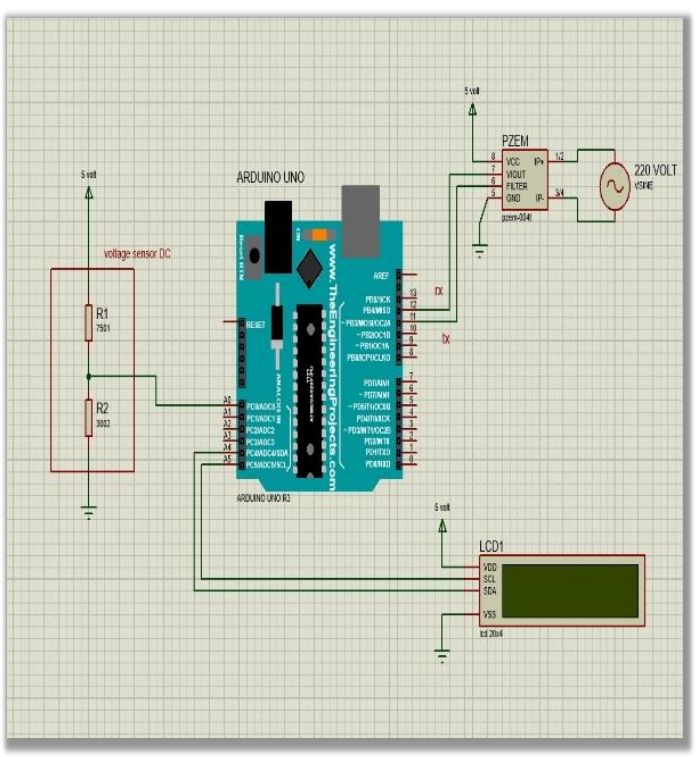

Gambar 5. Skema rangkaian

Pada skema rangkaian diatas, pin output dari sensor pzem terdiri dari pin rx dan pin tx. Untuk pin tx sensor PZEM dihubungkan ke pin 11 pada Arduino, sedangkan pin rx dihubungkan dengan pin 12 pada Arduino. Untuk pin Lcd memiliki 2 pin yang digunakan untuk komunikasi i2c, dari pin sda dihubungkan ke sda Arduino, sedangkan scl pada lcd dihubungkan ke pin scl Arduino. Untuk pin sensor tegangan dc dihubungkan pada pin A0 arduino. Tujuan dilakukan pemodelan simulasi rangkaian ini adalah untuk memudahkan dalam proses pembuatan alat. Sehingga dengan adanya skema rangkaian ini penulis dapat mengetahui pin mana saja yang dihubungkan dari komponen-komponen satu sama lain.

Pada alat ini sebelum melakukan proses pembuatan rangka, maka dibutuhkan proses perancangan mekanik terlebih dahulu, untuk perancangan desain mekanik pada alat ini menggunakan software sketchup. Untuk desain mekanik pada alat dapat dilihat pada Gambar 6.

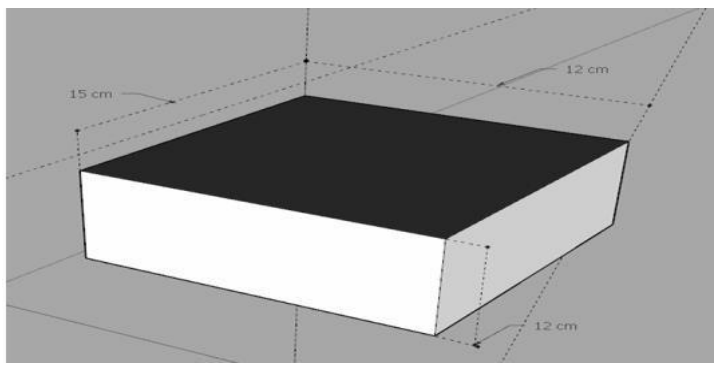

Gambar 6. Desain mekanik alat
Pengujian alat dilakukan berdasarkan flowchart yang terlihat pada Gambar 7.

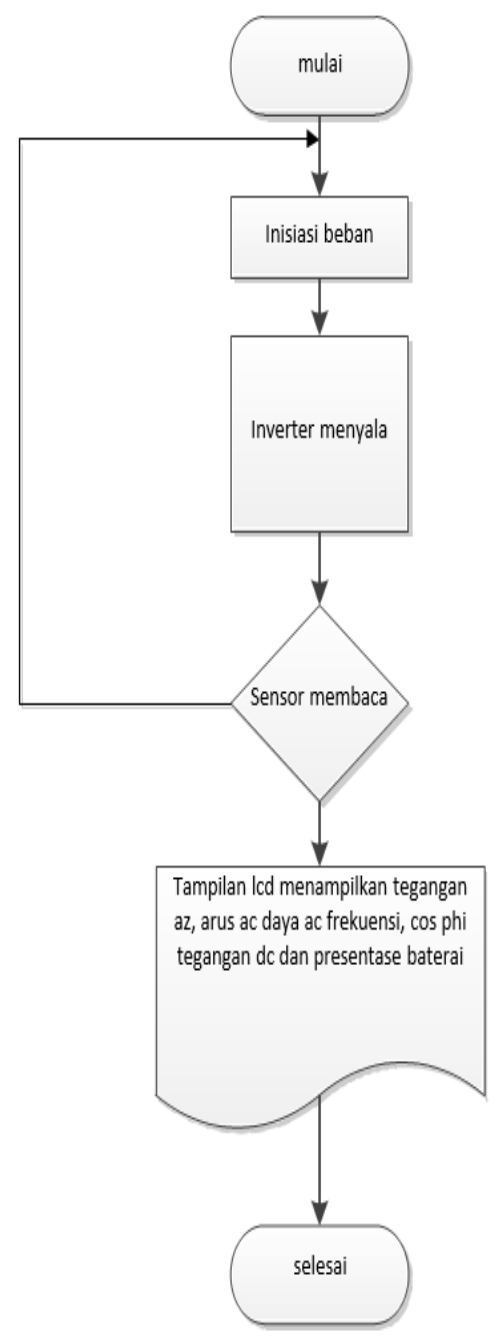

Gambar 7. Flowchart pengujian sensor

\section{Hasil dan Pembahasan}

Data yang didapatkan saat melalukan pengujian pada sistem monitoring penggunaan beban pada proses pengosongan baterai PLTS 100Wp menggunakan sensor PZEM-004T ialah berupa tegangan $\mathrm{AC}$, arus AC, daya, frequensi, cosphi, tegangan DC dan kapasitas baterai menggunakan beban yang berbeda berupa lampu pijar dengan kapasitas sebesar $18 \mathrm{~W}$ dan lampu TL berkapasitas sebesar $20 \mathrm{~W}$. Hasil Pengukuran Lampu Pijar 18 W dan Lampu TL 20 W dapat dilihat pada Tabel 1.

Pada Tabel 1. didapatkan Hasil pengukuran lampu pijar $18 \mathrm{~W}$ dan lampu TL $20 \mathrm{~W}$ dapat dilihat bahwa kemampuan alat monitoring dapat membaca tegangan, arus dan daya dari output inverter mulai dari pukul 18.00 WIB sampai dengan pukul 23.00 WIB yang beroperasi selama 5 jam dengan daya total beban sebesar $38 \mathrm{~W}$. 
TABEL 1

Hasil Pengukursn Lampu PiJar 18 W dan

LAMPU TL $20 \mathrm{~W}$

\begin{tabular}{lccccccc}
$\begin{array}{c}\text { Waktu } \\
(\text { WIB })\end{array}$ & \multicolumn{9}{c}{ Hasil Pembacaan } & \multirow{2}{*}{$\begin{array}{c}\text { Kapasitas } \\
\text { Baterai }\end{array}$} \\
\cline { 2 - 6 } & $\begin{array}{c}\text { Tegangan } \\
\text { AC }(\mathbf{V})\end{array}$ & $\begin{array}{c}\text { Arus AC } \\
(\mathbf{A})\end{array}$ & $\begin{array}{c}\text { Daya } \\
(\mathbf{W})\end{array}$ & $\begin{array}{c}\text { Frekuensi } \\
(\mathbf{H z})\end{array}$ & $\mathbf{C o s} \boldsymbol{\varphi}$ & $\begin{array}{c}\text { Tegangan } \\
\mathbf{D C}(\mathbf{V})\end{array}$ & \\
\hline 18.00 & 229,50 & 0,28 & 38,50 & 49,9 & 0,61 & 13,23 & $92 \%$ \\
19.00 & 229,90 & 0,27 & 38,10 & 49,9 & 0,60 & 12,77 & $85 \%$ \\
20.00 & 229,90 & 0,28 & 38,90 & 49,8 & 0,61 & 11,67 & $78 \%$ \\
21.00 & 229,80 & 0,28 & 39,50 & 49,8 & 0,62 & 11,52 & $78 \%$ \\
22.00 & 228,60 & 0,28 & 40,50 & 49,8 & 0,63 & 11,50 & $78 \%$ \\
23.00 & 228,60 & 0,28 & 40,40 & 49,8 & 0,62 & 11,38 & $78 \%$ \\
\hline
\end{tabular}

Hasil pembacaan sensor tegangan AC dengan selisih perbandingan manual dapat dilihat pada Tabel 2.

TABEL 2

Hasil Perbandingan Tegangan AC PembacaAn SENSOR DENGAN PEMBaCAan Alat UKur

\begin{tabular}{ccccc}
\hline $\begin{array}{c}\text { Waktu } \\
\text { (WIB) }\end{array}$ & $\begin{array}{c}\text { Pembac } \\
\text { aan } \\
\text { Sensor } \\
\text { Tegang } \\
\text { an AC } \\
(\mathbf{V})\end{array}$ & $\begin{array}{c}\text { Pembacaan } \\
\text { alat ukur } \\
(\mathbf{V})\end{array}$ & $\begin{array}{c}\text { Selisih } \\
\text { Persentase }\end{array}$ & $\begin{array}{c}\text { Pesalahan } \\
\text { K\%) }\end{array}$ \\
\hline 18.00 & 229,50 & 220 & 9,5 & 4,31 \\
19.00 & 229,90 & 220 & 9,9 & 4,5 \\
20.00 & 229,90 & 220 & 9,9 & 4,5 \\
21.00 & 229,80 & 220 & 9,8 & 4,45 \\
22.00 & 228,60 & 210 & 18,6 & 8,85 \\
23.00 & 228,60 & 210 & 18,6 & 8,85 \\
\hline
\end{tabular}

Pada Tabel 2. hasil perbandingan tegangan AC dengan alat ukur di atas dapat diambil analisa bahwa pengujian tegangan AC dilakukan untuk mengetahui kemampuan dan kinerja sensor tersebut. Pada pengujian tegangan AC ini menggunakan sensor PZEM-004T yang dapat membaca output keluaran yang dari inverter.. Sensor tegangan AC berfungsi untuk mengukur tegangan pada beban yang kemudian dikirimkan ke Arduino UNO328 untuk diproses nilai data dan dikonfersikan pada LCD sehingga nilai data dapat dibaca atau ditampilkan. Berdasarkan Tabel 2. pengujian sensor tegangan AC sudah bekerja sesuai fungsinya. Data pada Tabel 2. menunjukan bahwa pada saat tegangan sumber turun pembacaan sensor juga mengikuti, begitu pula sebaliknya jika tegangan sumber naik maka pembacaan sensor juga akan naik. Persentase kesalahan pengukuran tegangan paling besar, yaitu $8,85 \%$. Persentase rata-rata kesalahan pengukuran berdasarakan pada persamaan (4) dapat dihitung sebagai berikut:

rata - rata kesalahan

$$
\begin{gathered}
=\frac{\text { jumlah persentase kesalahan }}{\text { jumlah data }} \times 100 \% \\
=\frac{33,26}{6} \times 100 \% \\
=5,54 \%
\end{gathered}
$$

Berikut hasil pembacaan Arus dengan selisih perbandingan manual dapat dilihat pada Tabel 3. Pada Tabel 3. Hasil perbandingan arus AC pembacaan sensor dengan perhitungan manual menggunakan sensor PZEM-004T, pengujian sensor arus digunakan untuk mengetahui kinerja dari sensor PZEM-004T tersebut. Pengujian dilakukan dengan cara membandingkan hasil pengukuran yang didapatkan dari sensor dengan perhitungan manual, hasil dari perhitungan manual didapatkan dengan cara yaitu: Tegangan beban dibagikan dengan besar beban, hasil data sensor arus AC didapatkan dengan cara menghubungkan beban pada output inverter, setelah itu data nilai yang konsumsi oleh beban akan dilakukannya pengukuran oleh sensor dan diproses oleh Arduino UNO328 kemudian dikonfersikan ke LCD sehingga nilai yang didapatkan oleh sensor dapat dibaca dan ditampilkan ke pembacaan LCD. Pada pengujian menggunakan beban lampu pijar sebesar $18 \mathrm{~W}$ dan lampu TL sebesar $20 \mathrm{~W}$. Nilai selisih terbesar yaitu; 0,11 A , besaran arus seharusnya yaitu; 0,17 A, namun pada pembacaan sensor sebesar 0,28 A. Dari pengujian yang telah dilakukan dapat dihitung persentase rata-rata kesalahan sensor arus AC dengan persamaan (4) dapat dihitung sebagai berikut rata - rata kesalahan

$$
\begin{gathered}
=\frac{\text { jumlah persentase kesalahan }}{\text { jumlah data }} \times 100 \% \\
=\frac{145,84}{6} \times 100 \% \\
=24,3 \%
\end{gathered}
$$


TABEL 3

Hasil Perbandingan Arus aC Pembacaan Sensor dengan Perhitungan manual

\begin{tabular}{ccccccc}
\hline $\begin{array}{l}\text { Waktu } \\
\text { (WIB) }\end{array}$ & $\begin{array}{c}\text { Pembacaan } \\
\text { Arus AC } \\
(\mathbf{V})\end{array}$ & $\begin{array}{c}\text { Besar } \\
\text { Beban } \\
(\mathbf{W})\end{array}$ & $\begin{array}{c}\text { Tegangan } \\
\text { Beban } \\
(\mathbf{V})\end{array}$ & $\begin{array}{c}\text { Perhitungan } \\
\text { Arus (A) }\end{array}$ & Selisih & $\begin{array}{c}\text { Persentase } \\
\text { Kesalahan } \\
(\%)\end{array}$ \\
\hline 18.00 & 0,28 & 38,5 & 220 & 0,17 & 0,11 & 39,28 \\
19.00 & 0,27 & 38,1 & 220 & 0,17 & 0,1 & 10 \\
20.00 & 0,28 & 38,9 & 220 & 0,17 & 0,11 & 39,28 \\
21.00 & 229,80 & 39,5 & 220 & 0,17 & 0,11 & 39,28 \\
22.00 & 228,60 & 40,5 & 210 & 0,19 & 0,09 & 9 \\
23.00 & 228,60 & 40,4 & 210 & 0,19 & 0,09 & 9 \\
\hline
\end{tabular}

Pada perhitungan menentukan nilai daya sebenarnya bertujuan untuk mengetahui apakah pembacaan daya pada sensor sesuai dengan nilai perhitungan manual, dengan cara mengalikan tegangan sumber output inverter yang bernilai sebesar $220 \mathrm{~V}$ dengan arus yang didapatkan oleh pembacaan sensor dan cosphi yang terbaca oleh sensor, sehingga dapat mengetahui berapakah daya sebenarnya yang disuplay oleh beban, dengan menggunakan persamaan (2), sebagai berikut:

a. Awal saat beban terpasang

$$
\begin{aligned}
P & =V \times I \times \cos \varphi \\
& =220 \times 0,28 \times 0,61 \\
& =37,57 \mathrm{~W}
\end{aligned}
$$

b. Saat beban terpasang setelah 1 jam

$$
\begin{aligned}
P & =V \times I \times \cos \varphi \\
& =220 \times 0,27 \times 0,60 \\
& =37,64 \mathrm{~W}
\end{aligned}
$$

c. Saat beban terpasang setelah 2 jam

$$
\begin{aligned}
P & =V \times I \times \cos \varphi \\
& =220 \times 0,27 \times 0,61 \\
& =37,57 \mathrm{~W}
\end{aligned}
$$

d. Saat beban terpasang setelah 3 jam

$$
\begin{aligned}
P & =V \times I \times \cos \varphi \\
& =220 \times 0,27 \times 0,62 \\
& =38,2 \mathrm{~W}
\end{aligned}
$$

e. Saat beban terpasang setelah 4 jam

$$
\begin{aligned}
P & =V \times I \times \cos \varphi \\
& =220 \times 0,27 \times 0,63 \\
& =38,8 \mathrm{~W}
\end{aligned}
$$

f. Saat beban terpasang setelah 5 jam

$$
\begin{aligned}
P & =V \times I \times \cos \varphi \\
& =220 \times 0,27 \times 0,62 \\
& =38,2 \mathrm{~W}
\end{aligned}
$$

\begin{tabular}{|c|c|c|c|c|}
\hline \multirow[t]{2}{*}{$\begin{array}{l}\text { Waktu } \\
\text { (WIB) }\end{array}$} & \multicolumn{3}{|c|}{$\begin{array}{c}\text { Hasil Perhitungan Daya } \\
\text { Sebenarnya }\end{array}$} & \multirow{2}{*}{$\begin{array}{c}\text { Perse } \\
\text { ntase } \\
\text { Kesal } \\
\text { ahan } \\
(\%)\end{array}$} \\
\hline & $\begin{array}{l}\text { Pembaca } \\
\text { an Sensor } \\
(\mathrm{W})\end{array}$ & $\begin{array}{l}\text { Perhitungan } \\
\text { Manual (W) }\end{array}$ & Selisih & \\
\hline 18.00 & 38,50 & 37,57 & 0,93 & 2,41 \\
\hline 19.00 & 38,10 & 35,64 & 2,46 & 6,45 \\
\hline 20.00 & 38,90 & 37,57 & 1,33 & 3,41 \\
\hline 21.00 & 39,50 & 38,20 & 1,30 & 3,29 \\
\hline 22.00 & 40,50 & 38,80 & 2,10 & 5,18 \\
\hline 23.00 & 40,40 & 38,20 & 2,20 & 5,44 \\
\hline
\end{tabular}

Berikut di bawah ini merupakan hasil dari perhitungan manual mencari nilai daya sebenarnya yang disuplay oleh beban selama 5 jam yang menggunakan persamaan (5), yaitu

$$
\begin{aligned}
P_{\text {sebenarnya }} & =V \times I \times \cos \varphi \times t \\
& =220 \times 0,28 \times 0,62 \times 5 \\
& =194,04 \mathrm{~W} / \mathrm{jam}
\end{aligned}
$$

Pada Tabel 4. disajikan hasil daya sebenarnya bertujuan untuk mengetahui kemampuan dan unjuk kerja sensor yang digunakan, apakah sistem pembacaan sesuai dengan perhitungan manual atau tidak sesuainya, sehingga dapat mengetahui berapakah nilai selisih antara pembacaan sensor dengan perhitungan manual.

TABEL 4

Hasil Perbandingan Daya Pembacaan Sensor DENGAN PERHITUNGAN DAYA SEBENARNYA

Pada Tabel 4. dapat dilihat persentase selisih terbesar antara pembacaan sensor dengan perhitungan manual sebesar $6,45 \%$ saat beban terpasang setelah waktu satu jam. Konsumsi daya sebenarnya yang disuplay oleh beban saat beban terpasang yaitu; 194,04 Watt selama 5 jam. Dari perbandingan daya pembacaan sensor dengan perhitungan manual yang telah dilakukan dapat dihitung persentase rata-rata kesalahan pembacaan sensor dengan persamaan (4), yaitu: rata - rata kesalahan

$$
\begin{gathered}
=\frac{\text { jumlah persentase kesalahan }}{\text { jumlah data }} \times 100 \% \\
=\frac{26,18}{6} \times 100 \% \\
=4,36 \%
\end{gathered}
$$

Pada perhitungan mencari nilai arus bertujuan untuk mengetahui apakah pembacaan arus pada sensor sesuai dengan nilai perhitungan manual, dengan cara membagikan daya yang didapat pada sensor dengan tegangan sumber output inverter yang bernilai sebesar $220 \mathrm{~V}$ dan cosphi yang terbaca oleh sensor, sehingga dapat mengetahui berapakah arus yang terpakai oleh beban yang disuplay selama perjam dengan menggunakan persamaan (6), yaitu:

1. Awal saat beban terpasang

$$
I=\frac{P}{V x \cos \varphi}=\frac{37,57}{220 \times 0,61}=0,27 \mathrm{~A}
$$

2. Saat beban terpasang setelah 1 jam 


$$
I=\frac{P}{V x \cos \varphi}=\frac{35,64}{220 \times 0,6}=0,27 \mathrm{~A}
$$

3. Saat beban terpasang setelah 2 jam

$$
I=\frac{P}{V x \cos \varphi}=\frac{37,57}{220 \times 0,61}=0,28 \mathrm{~A}
$$

4. Saat beban terpasang setelah 3 jam

$$
I=\frac{P}{V x \cos \varphi}=\frac{38,20}{220 \times 0,62}=0,28 \mathrm{~A}
$$

5. Saat beban terpasang setelah 4 jam

$$
I=\frac{P}{V x \cos \varphi}=\frac{38,80}{220 \times 0,63}=0,28 \mathrm{~A}
$$

6. Saat beban terpasang setelah 5 jam

$$
I=\frac{P}{V x \cos \varphi}=\frac{38,20}{220 \times 0,62}=0,28 \mathrm{~A}
$$

Berikut di bawah ini merupakan hasil dari perhitungan manual mencari nilai arus sebenarnya yang terpakai oleh beban selama 5 jam, yang menggunakan rumus persamaan (7), yaitu:

$$
\begin{aligned}
I_{\text {sebenarnya }} & =\frac{P_{\text {beban }}}{V x \cos \varphi \times t e} \\
& =\frac{38,20}{220 \times 0,62 \times 5} \\
& =0,056 \text { Ampere } / \mathrm{jam}
\end{aligned}
$$

Pada Tabel 5. disajikan hasil perbandingan arus pembacaan sensor dengan perhitungan arus sebenarnya

\begin{tabular}{|c|c|c|c|c|}
\hline \multirow[t]{2}{*}{$\begin{array}{l}\text { Waktu } \\
\text { (WIB) }\end{array}$} & \multicolumn{3}{|c|}{$\begin{array}{c}\text { Hasil Perhitungan Arus } \\
\text { Sebenarnya } \\
\end{array}$} & \multirow{2}{*}{$\begin{array}{c}\text { Perse } \\
\text { ntase } \\
\text { Kesal } \\
\text { ahan } \\
(\%)\end{array}$} \\
\hline & $\begin{array}{c}\text { Pembaca } \\
\text { an Sensor } \\
\text { (A) }\end{array}$ & $\begin{array}{c}\text { Perhitung } \\
\text { an } \\
\text { Manual } \\
\text { (A) }\end{array}$ & Selisih & \\
\hline 18.00 & 0,28 & 0,27 & 0,01 & 3,57 \\
\hline 19.00 & 0,27 & 0,27 & 0 & 0 \\
\hline 20.00 & 0,28 & 0,28 & 0 & 0 \\
\hline 21.00 & 0,28 & 0,28 & 0 & 0 \\
\hline 22.00 & 0,28 & 0,28 & 0 & 0 \\
\hline 23.00 & 0,28 & 0,28 & 0 & 0 \\
\hline
\end{tabular}
bertujuan untuk mengetahui kemampuan dan unjuk kerja sistem sensor yang telah dibuat, apakah nilai pembacaan sensor sesuai dengan perhitungan manual atau tidaknya.

TABEL 5

Hasil Perbandingan Arus Pembacaan Sensor Dengan Perhitungan Arus Sebenarnya

Pada Tabel 5. diatas dapat diambil analisa bahwa kemampuan dan unjuk kerja pada sensor dapat dikatakan sudah bekerja dengan semestinya, karena persentase selisih hanya tertuju pada pengujian awal saat beban terpasang yang bernilai sebesar 3,57 \%.
Konsumsi arus sebenarnya yang disuplay oleh beban saat beban terpasang yaitu; 1,4 Ampere selama 5 jam.

Pada Tabel 6. Disajikan nilai kapasitas baterai pada pengujian dengan menggunakan beban yaitu: lampu pijar berkapasitas sebesar $18 \mathrm{~W}$ dan lampu TL berkapasitas sebesar $20 \mathrm{~W}$ yang disuplay dari jam 18.00 WIB sampai dengan 20.00 WIB kapasitas baterai menurun setiap perjam sebesar $7 \%$. Sedangkan pada jam 20.00 WIB sampai dengan jam 23.00 WIB kapasitas baterai tidak berkurang atau konstan sebesar $78 \%$. Dengan menggunakan lampu pijar dan lampu TL yang dihubungkan secara bersamaan, dengan kapasitas sebesar $12 \mathrm{~V}$ 45AH dapat menyuplai beban selama 5 jam dengan konsumsi daya sebesar 197,4 baterai Watt dan konsumsi arus selama 5 jam sebesar 1,4 Ampere.

TABEL 6

KAPASITAS BATERAI DENGAN BEBAN LAMPIJAR $18 \mathrm{~W}$ DAN LAMPU TL $20 \mathrm{~W}$

\begin{tabular}{ccc}
\hline Waktu (WIB) & Beban & $\begin{array}{c}\text { Kapasitas } \\
\text { Baterai }(\%)\end{array}$ \\
\hline 18.00 & Pijar +TL & 92 \\
19.00 & Pijar +TL & 85 \\
20.00 & Pijar +TL & 78 \\
21.00 & Pijar +TL & 78 \\
22.00 & Pijar +TL & 78 \\
23.00 & Pijar +TL & 78 \\
\hline
\end{tabular}

Pada Tabel 7. disajikan nilai kapasitas baterai pada pengujian dengan menggunakan lampu pijar berkapasitas sebesar $36 \mathrm{~W}$ diperoleh nilai kapasitas baterau menurun dalam perjam tertuju pada jam 20.00 WIB sebesar $7 \%$ dan pada jam 21.00 WIB setelah ditambahkan lampu TL berkapasitas $30 \mathrm{~W}$ samapai dengan jam 22.00 WIB kapasitas baterai menurun sebesar $7 \%$. Dengan menggunakan lampu pijar dan lampu TL secara bertahap, dengan menggunakan kapasitas baterai sebesar $12 \mathrm{~V} 45 \mathrm{AH}$ hanya dapat menyuplai beban selama 4 jam dengan konsumsi daya sebesar 226,8 W dan konsumsi arus selama 4 jam sebesar 1,48 Ampere.

TABEL 7

KAPASITAS BATERAI DENGAN BEBAN LAMPIJAR 32 W DAN LAMPU TL $30 \mathrm{~W}$

\begin{tabular}{ccc}
\hline Waktu (WIB) & Beban & $\begin{array}{c}\text { Kapasitas } \\
\text { Baterai }(\%)\end{array}$ \\
\hline 18.00 & Pijar & 92 \\
19.00 & Pijar & 92 \\
20.00 & Pijar & 85 \\
21.00 & Pijar +TL & 85 \\
22.00 & Pijar +TL & 78 \\
\hline
\end{tabular}


Pada perbandingan kapasitas baterai dapat di ambil analisa bahwa pada pengujian pertama dan kedua, menurunnya kapasitas bateraisebesar $7 \%$ yaitu sama, perbedaannya hanya pada waktu dan jenis beban yang digunakan pada saat menyuplai beban. Semakin besar tahanan beban yang disuplai maka semakin besar pula kapasitas baterai yang berkurang/habis dan daya tahan baterai akan lebih singkat. Dalam penelitia kali ini jumlah kapasitas baterai yang bisa di gunakan hanya sebesar $22 \%$ hal ini di karenakan pengaruh dari Deep Off Discharge (DOD) baterai, umumnya Deep Off Discharge (DOD) pada suatu baterai sebesar $80 \%$, tetapi dalam penelitian kali ini hanya sebesar $22 \%$, hal ini sesuai dengan jurnal (Sianipar, 2014) yang mengatakan bahwa Deep Off Discharge (DOD) untuk 1 baterai PLTS adalah sebesar 25-30\%. Untuk hasil pembacaan persentase baterai ditentukan secara otomatis oleh program mapping, cara kerja dari program mapping yang digunakan dalam penelitian kali ini adalah apabila hasil pembacaan tegangan turun sebesar $1 \mathrm{~V}$ maka persentase baterai akan turun sebesar $7 \%$, nilai tersebut didapatkan dari proses pengimputan nilai high dan nilai low yang dimasukan kedalam program mapping dengan nilai low sebesar $11,38 \mathrm{~V}$ dan nilai high sebesar $14,11 \mathrm{~V}$. sedangkan penyebab terjadinya penurunan sebesar $8 \%$ saat inverter pertama kali dihubungkan ke baterai adalah akibat dari sifat inverter itu sendiri yang dapat menyimpan arus dan tegangan.

\section{KESIMPULAN}

Berdasarkan hasil pengujian dan pembahasan alat monitoring penggunaan beban pada proses pengosongan baterai PLTS 100Wp menggunakan sensor PZEM-004T, dapat diambil beberapa kesimpulan sebagai berikut :

1. Sistem monitoring pengosongan baterai PLTS menggunakan sensor PZEM-004T berhasil di aplikasikan pada proses pengosongan sebagai alat untuk memonitor kinerja dan kapasitas baterai yang berkemampuan dapat melakukan pembacaan
Jurnal Amplifier Mei 2021 Vol 11 No 1 P-ISSN 2089-2020 dan E-ISSN 2622-2000 nilai tegangan, arus dan daya pada saat menyuplai beban.

2. Masing-masing pembacaan sensor memiliki nilai persentase selisih yang diantaranya pada pembacaan arus AC yang dibandingkan dengan perhitungan manual memiliki persentase kesalahan sebesar $4,91 \%$.

3. Besar nilai tahanan beban yang digunakan pada proses pengosongan baterai sangat berpengaruh terhadap baterai tersebut, semakin besar daya yang terpasang maka semakin besar juga arus yang digunakan dan baterai akan lebih cepat habis/waktu penggunaan baterai menjadi lebih singkat.

\section{Daftar Pustaka}

[1] Priyatman, H., "Analisa Efesiensi Pada Rancang Bangun Solar Home System", 2016.

[2] Salman, R., "Analisis Perencanaan Penggunaan Sistem Pembangkit Listrik Tenaga Surya (Plts) Untuk Perumahan (Solar Home System) $)^{e c}$, Majalah Ilmiah Bina Teknik, Vol. 1(1), pp. 46-51, 2013.

[3] Sidik, M. dkk, "Potensi Dan Peranan PLTS Sebagai Energi Alternatif Masa Depan di Indonesia", 2012.

[4] Siregar, R.A. dkk,"Sistem Monitoring Kinerja Panel Listrik Tenaga Surya Menggunakan Arduino UNO $^{e}$, Jurnal TETri Universitas Trisakti Vol. 14(2), pp. 81-100, 2017.

[5] Sianipar, R., "Dasar Perencanaan Pembangkit Listrik Tenaga Surya ${ }^{\text {ee }}$, Jurnal TETri Universitas Trisakti Vol.11(2), pp. 61-78. 2014.

[6] Mudaris, R., "Analisis penggunaan inverter pure sine wave (psw) satu phasa 500 watt terhadap efisiensi beban RLC pada PLTS kapasitas $100 \mathrm{WP}^{\mathrm{ee}}$, Malaysian Palm Oil Council (MPOC), 21(1), pp. 19, 2020.

[7] Rusman, R. "Pengaruh Variasi Beban Terhadap Efisiensi Solar Cell Dengan Kapasitas $50 \mathrm{WP}^{\mathrm{e}}$, Turbo: Jurnal Program Studi Teknik Mesin, Vol. 4(2). 2017. [8] 